\title{
Store endringer i tarmfloraen ved primær skleroserende kolangitt
}

\author{
Studier av tarmfloraen hos pasienter med primær skleroserende kolan- \\ gitt og tilhørende musemodeller indikerer en potensielt viktig rolle for \\ tarmfloraen i utviklingen av gallegangssykdom.
}

Primær skleroserende kolangitt er en kronisk leversykdom med progressiv gallegangsbetennelse og ukjent etiologi som i stor grad rammer unge mennesker. Majoriteten lider også av inflammatorisk tarmsykdom. Det finnes ingen effektiv behandling, og det har lenge vært den vanligste indikasjonen for levertransplantasjon i Norden. Tarmfloraen er i de senere år implisert i utviklingen av flere inflammatoriske sykdommer.

I mitt doktorarbeid gjennomførte vi den hittil største studien av tarmfloraen hos pasienter med primær skleroserende kolangitt. I tillegg undersøkte vi en bakterieavhengig metabolitt i blodet ved sykdommen, og tarmfloraens betydning hos mus med lignende gallegangssykdom.

Vi identifiserte flere endringer i tarmfloraen hos pasientene våre. Bakteriemangfol- det var betydelig redusert. Vi så endret forekomst i flere grupper bakterier, deriblant økte nivåer av Veillonella, som er assosiert med flere fibrotiske tilstander. Høye nivåer av den bakterieavhengige metabolitten trimetylamin-N-oksid var assosiert med dårlig prognose. I studier av mus som spontant utvikler gallegangssykdom viste vi at tarmfloraen i betydelig grad bidrar til utviklingen av denne sykdommen.

Samlet tyder funnene på at tarmfloraen potensielt kan ha betydning for utviklingen av primær skleroserende kolangitt. Dette åpner på sikt opp for manipulasjon av tarmfloraen som en behandlingsmulighet.

\section{Martin Kummen}

martin.kummen@medisin.uio.no

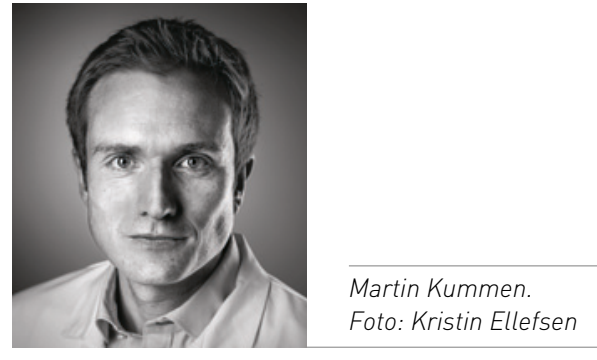

Disputas

Martin Kummen disputerte for ph.d.-graden ved Universitetet i Oslo 4.10. 2016. Tittelen på avhandlingen er Primary sclerosing cholangitis and the gut microbiota - a study on mice, man and microbes.

\section{Vekst og hjerneutvikling hos premature barn}

Å gi omega 3 og 6 til premature kan ha effekt på kognitiv utvikling første leveår. Ved åtte års alder fant vi ikke lenger sikker effekt.

Premature barn har økt risiko for kognitive senskader med lavere IQ, atferdsproblemer og redusert hjerneutvikling målt ved MR.

De har også endret vekst og metabolsk profil, med høyere risiko for diabetes og hjerteog karsykdom. Tilskudd av omega 3 og 6 i nyfødtperioden ga i vår opprinnelige studie bedre kognitiv funksjon første leveår. Vi ønsket å se om effekten fortsatt var målbar ved åtte års alder.

Vi har gjort en oppfølgingsstudie av disse prematurt fødte barna ved åtte års alder. Barna ble innkalt til MR caput for vurdering av hjernevolum og myelinisering, samt et bredt utvalg av kognitive tester, vekstmålinger og blodprøver på metabolske faktorer. Ved åtte års alder var det ikke lenger målbar effekt av intervensjonen på MR, kognitive data eller atferd. Det var ingen forskjell i vekst mellom de to gruppene. Veksthastighet første leveår hadde ikke betydning for kroppsmasseindeks eller IQ ved åtte år. Gruppen som fikk omega 3 og 6 hadde lavere IGF-1, som kan tyde på at intervensjonen kan ha effekt på metabolske prosesser senere i livet.

Studien er den første langtidsoppfølging av premature som kombinerer MR, kognitive tester og metabolsk profil etter intervensjon med omega 3 og 6 . Det er stort fokus på faktorer som kan forhindre nevrokognitiv og metabolsk sekvele hos premature, og studien er et bidrag i jakten på optimal behandling av fremtidens premature.

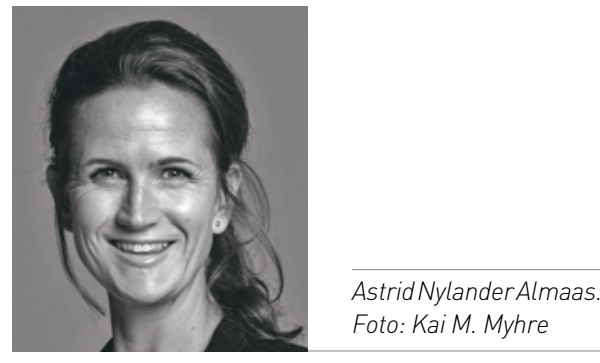

Disputas

Astrid Nylander Almaas disputerte for ph.d.graden ved Universitetet i Oslo 12.09. 2016. Tittelen på avhandlingen er Brain development cognition and growth in 8-year old children born prematurely. Follow-up of a randomized controlled trial with docosahexaenoic acid and arachidonic acid. 